\title{
Barkhausen Noise Emission of Surfaces after Laser Beam Machining
}

Alena Vajdova Anna Micietova, Maria Cillikova, Miroslav Neslusan

University of Žilina, Faculty of Mechanical Engineering, Univerzitná 1, 01026 Žilina, Slovak republic;

E-mail: anna.micietova@fstroj.uniza.sk, alena.vajdova@fstroj.uniza.sk, maria.cillikova@fstroj.uniza.sk, miroslav.neslusan@fstroj.uniza.sk.

This paper deals with analysis of surface integrity of steel after laser beam machining (LBM). The paper discusses surface integrity expressed in term of rms values of Barkhausen noise and reports about variables affecting Barkhausen noise emission such as laser power, gas pressure, thickness of machined surface, focus distance and feed speed. The paper demonstrates variable degree of surface hardening due to elevated temperatures and the following rapid cooling. Except magnetic investigation of surface also stress state and structure observation are reported. This study demonstrates that thickness samples takes major role from the point of surface integrity expressed in structure transformations as well as stress state whereas influence of focus distance and gas pressure are only minor. Medium degree of surface integrity transformation can be driven by variation of laser power and feed speed.

Keywords: laser beam machining, Barkhausen noise, surface hardening

\section{Acknowledgement}

This project is solved under the financial support of KEGA agency (project n. 009ŽU-4/2014 and 005ŽU-4/2014) and project CZ-SK 2013-0017.

\section{References}

[1] MIČIETOVÁ, A. (2007) Nekonvenčné metódy obrábania - výber, využitie, perspektívy, EDIS Žilina, ISBN 978 80-8070-775-0.

[2] MIČIETOVÁ, A., MAŇKOVÁ, I., VELÍŠEK, K. (2007). Top trendy v obrábaní, V. čast' - Fyzikálne technológie obrábania, MEDIA/ST, s.r.o., Žilina, ISBN 80-968954-7-2.

[3] MAŇKOVÁ, I. (2000). Progresívne technológie, Vienala, Košice.

[4] PARANDOUSH, P., HOSSAIN, A. (2014). A review of modeling and simulation of LBM, In: International Journal of Machine Tools and Manufacture, Vol. 85, pp. 135-145.

[5] MEIJER, J. (2004). Laser beam machining (LBM), state of the art and new opportunities, In: Journal of Material Processing Technology, Vol. 149, pp. 2-17.

[6] MIČIETOVÁ, A., NESLUŠAN, M., ČILLIKOVÁ, M. (2013). Influence of surface geometry and structure after non-conventional methods of parting on the following milling operation, In: Manufacturing technology, Vol.13, pp. 199-204.

[7] MIČIETOVÁ, A., NESLUŠAN, M., ČILLIKOVÁ, M. (2013). Residual stresses after thermal methods parting, In: Machines Technologies Materials, Vol. 2, pp. 235 - 240.

[8] VAJDOVÁ, A. el all. (2014). Analysis of surface integrity of parts after non conventional methods of machining, In: Manufacturing technology, Vol.14, pp. 470-474

[9] KAMEDA, J., RANJAN, R. (1987). Nondestructive evaluation of steels using acoustic and magnetic Barkhausen signals - II. Effect of inter granular impurity segregation, In: Acta Metall., Vol. 35/7, 1987, pp. 1527-1531.

[10] BUTTLE, D.J., et all. (1991). Magneto-acoustic and Barkhausen emission: their dependence on dislocations in iron, In: NDT \& E Int., Vol. 24, pp.47 - 54.

[11] GATELIER-ROTHEA, C., et all. (1998). Characterization of pure iron and carbon-iron binary alloy by Barkhausen noise measurements: study of the influence of stress and microstructure, In: Acta Mater. Vol. 46/14, 1998, pp.4873-4882.

[12] RANJAN, R., JILES, C., RASTOGI, P. (1987). Magnetic properties of decarburized steels: An investigation of the effects of grain size and carbon content, In: IEEE Trans. Magn., Vol. 23/3, 1987, pp.1869-1876.

[13] DURSTOVÁ, Z. et all. (2014). Non-destructive evaluation of ground surfaces made of bearing steel of variable hardness, In: Manufacturing technology, Vol.14, 2014, pp. 297-303. 
[14] ČILLIKOVÁ, M. et all. (2014). Detection of surface damage after grinding of large case-hardened bearing rings, In: Engineering materials, Vol. 581, pp. 205-210.

[15] BLAOW, M., EVANS, J., SHAW, B. (2005). Magnetic Barkhausen noise: the influence of microstructure and deformation in bending, In: Acta Materialia, Vol. 53, pp.279-287.

[16] MOORTHY, V. et all. (2001). Evaluation of heat treatment and deformation induced changes in material properties in gear steels using magnetic Barkhausen noise analysis, ICBN 03 Tampere, Finland.

[17] MIČIETOVÁ, A., NESLUŠAN, M., ČILLIKOVÁ, M. (2013). Influence of surface geometry and structure after non-conventional methods of parting on the following milling operations, In: Manufacturing technology, Vol.13, pp. 199-204.

[18] BREZANI, J. (2012). Model vzájomných relácií pri termickom rezaní materiálov, PhD. Thesis, University of Žilina

[19] MIČIETA, B., BIŇASOVÁ, V., HALUŠKA, M. (2014). Reconfigurable manufacturing system and sustainable production, 1. vyd. - Saarbrücken : LAP LAMBERT Academic Publishing, 86 s. ISBN 978-3-659-59101-3

[20] MEŠKO, J. et all. (2014). Microstructure analysis of welded joints efter laser welding, In: Manufacturing technology, Vol.14, pp. 355-359 